\title{
Penambahaan Tepung Spirulina dalam Pakan Terhadap Performa Warna Ikan Hias Komet (Carassius auratus)
}

\author{
[Supplementation of Spirulina meal in the commercial diet on the colour performance of \\ goldfish (Carassius auratus)]
}

\author{
Anwar*, Agus Kurnia, Indriyani Nur \\ Program Studi Budidaya Perairan, Fakultas Perikanan dan Ilmu Kelautan Universitas Halu Oleo \\ JL. HAE Mokodompit Kampus Bumi Tridharma Anduonohu Kendari, Indonesia 93232 Tel/Fax (0401) 3193782 \\ *Email korespondensi: andikaanwar140696@gmail.com
}

\begin{abstract}
ABSTRAK
Penelitian ini bertujuan untuk mengetahui penambahan tepung Spirulina dalam pakan terhadap performa warna ikan hias komet $(C$. auratus). Empat jenis pakan uji dibuat berdasarkan dosis penambahan tepung Spirulina dalam pakan yakni pakan komersil tanpa penambahan tepung Spirulina (pakan A), penambahan 1\% tepung Spirulina dalam pakan (pakan B), penambahan 3\% tepung Spirulina dalam pakan (pakan C), dan penambahan 5\% tepung Spirulina dalam pakan (pakan D). Penelitian ini dilaksanakan selama 40 hari. Sebanyak 60 ekor ikan komet dengan bobot rata-rata awal8.02 $\pm 1,02 \mathrm{~g}$ yang ditempatkan ke dalam 12 akuarium (5 ekor/akuarium). Tingkat kecerahan warna ikan ditentukan dengan menggunakan metode score sheet dengan melibatkan 10 orang panelis. Hasil penelitian menunjukkan bahwa tingkat kecerahan warna orange tertinggi didapatkan pada ikan komet yang diberi pakan D sebesar 3.60, kemudian diikutipakan C, B dan A masing-masing sebesar 3.16, 2.62 dan 1.96. Tingkat kecerahan warna putih tertinggi juga didapatkan pada ikan komet yang diberi pakan D sebesar 2.94, kemudian diikuti pakan C, B dan A masing-masing sebesar 2.60, 1.92 dan 1.78, pertumbuhan mutlak ikan komet berkisar antara57.85-.32.7 dan kelangsungan hidup ikan komet selama penelitian adalah100\%.Penelitian ini menyimpulkan bahwa penambahan 5\% tepung Spirulina dalam pakan dapat meningkatkan kecerahan warna ikan hias komet.
\end{abstract}

Kata kunci : ikan komet, kecerahan warna, tepung spirulina, pakan komersial

\section{ABSTRACT}

This study aims to determine the supplementation of Spirulina meal in the commercial diet on the colour performance of goldfish (Carassius auratus) .Four experimental diets were prepared to contain different dosage of spirulina meal in the diet, namely commercial diet without spirulina meal (Diet A), $1 \%$ of spirulina meal supplemented into commercial diet (Diet B), $3 \%$ of spirulina meal supplemented into commercial diet (Diet C)and 5\% of spirulina meal supplemented into commercial diet (Diet D). for 40 days of rearing period. A total of sixty fish was distributed into 12 glass tanks (5 fish/glass tank) Colour brightness of fish were determined by using score sheet method with 10 panelist. The results showed that the fish fed diet $\mathrm{D}$ had highest in orange brightness colour in their skin (3.16) and followed by the fish fed $\operatorname{diet}$ C, diet B and diet A with values of 3.16, 2.62, and 1.96, respectively. While the highest of white brightness colour was also observed in the fish fed diet D (2.94) and followed by the fish fed diet C (2.60), diet B (1.92) and diet C (1.78). The weight gain of the fish were ranged between 57.8-32.7g. Survival rate of the fish till the end of the experiment were $100 \%$. This study concluded that supplementation of 5\% spirulina meal in the diet could improve the colour brightness of goldfish (Carrasius auratus)

Keywords: gold fish, skin colour brightness, spirulina meal, commercial diet

\section{PENDAHULUAN}

Sebagai negara produsen ikan hias dunia, kekayaan hayati Indonesia sudah banyak dikenal. Di dunia bisnis ikan hias, produk Indonesia dikenal memiliki banyak spesies, baik ikan hias air tawar maupun ikan hias air laut. Dari 1.100 spesies ikan hias air tawar yang ada di dunia, 400 spesies di antaranya berasal dari Indonesia. Salah satu ikan hias tersebut adalah ikan hias komet (Carassius auratus). Ikan hias komet merupakan salah satu jenis ikan hias air tawar yang memiliki keunggulan pada warna yang terdapat pada ikan tersebut yang bermacam-macam seperti putih, kuning, merah, atau perpaduan lain. Ikan komet berasal dari Cina dengan nama umum goldfish. Pada kalangan pembudidaya ikan hias di dunia, ikan komet termasuk salah satu ikan hias yang sangat populer dan banyak penggemarnya.

Salah satu indikator yang menjadi daya tarik konsumen terhadap ikan komet (C.auratus) adalah warna tubuh yang cerah dan beragam. Warna tubuh tersebut dipengaruhi oleh kandungan pigmen dalam pakan yang diberikan pada ikan. Pembentukan pada warna tubuh ikan disebabkan karena adanya sel pigmen yang terletak pada lapisan epidermis. 
Intesitas kecerahan warna pada ikan dapat ditingkatkan dengan menambahkan sumbersumber karotenoid pada pakan ikan (Bachtiar, 2002).

Warna merupakan salah satu alasan ikan hias diminati oleh masyarakat atau penghobi ikan hias. Namun lambat laun warna ikan hias ini akan memudar apabila selama pemeliharaanya diberi pakan yang mengandung sedikit atau tidak ada pewarna zat pigmen warna dalam pakannya. Hal ini disebabkan ini disebabkan ikan tidak dapat mensitesis/memproduksi pigmen warna dalam tubuhnya (Kurnia, 2013). Oleh karena itu zat pigmen warna harus ditambahkan dalam pakan untuk mempertahankan dan meningkatkan performa warna pada ikan hias.

Beberapa bahan pakan yang mengandung pigmen warna diantaranya adalah tepung spirulina. Bahan pewarna tersebut lebih dikenal dengan nama karotenoid. Karotenoid merupakan zat yang digunakan untuk pewarnaan kulit pada ikan. Efek dari adanya karatenoid antara lain dapat menyebabkan peningkatan kecerahan warna merah pada ikan. Hal tersebut menjadi akibat ekspresi pigmentasi beta-karoten atau astaksantin yang terkandung dalam tubuh ikan. Menurut pernyataan Yusniarti (2018) menunjukan bahwa penambahan karotenoid yang terkandung dalam tepung buah manggis dapat mempengaruhi kecerahan warna ikan komet

Potensi dan informasi mengenai pemanfaatan tepung spirulina dalam pakan sebagai zat pigmen untuk meningkatkan warna pada ikan hias komet masih terbatas. Oleh karena itu perlu dilakukan penelitian mengenai penambahan tepung spirulina dalam pakan terhadap performa warna ikan hias komet. Penelitian ini bertujuan untuk mengetahui pengaruh penambahan tepung Spirulina dalam pakan untuk pewarnaan ikan komet.

\section{BAHAN DAN METODE}

\section{Pakan Uji}

Pakan uji yang digunakan dalam penelitian ini adalah pakan komersial ikan hias yang ditambahkan tepung Spirulina,yang mengacu kepada Barus (2014). Proses pencampuran dilakukan dengan cara menyemprotkan tepung Spirulina yang dilarutkan dengan air hangat $40-60 \%$ pada pakan komersil sebanyak 100 gram. Jumlah tepung Spirulina yang ditambahkan dijadikan perlakuan pada penelitian ini yaitu Pakan A (pakan komersil tanpa penambahan tepung Spirulina), pakan B (pakan komersil dengan penambahan $1 \%$ tepung Spirulina), pakan C (pakan komersil dengan penambahan 3\% tepung Spirulina), dan pakan D (pakan komersil dengan penambahan 5\% tepung Spirulina).

Perlakuan disusun dengan menggunakan Rancangan Acak Lengkap (RAL) dengan 4 perlakuan dan 3 ulangan.

\section{Hewan Uji}

Hewan uji yang digunakan adalah ikan komet yang berasal dari 1 induk yang sama, dari Unit Pembenihan dan Produksi ikanFPIK UHO. Sebanyak 60 ekor ikan komet (bobot awal ratarata $8,02 \pm 1,02 \mathrm{~g}$ ) ditebar ke dalam 12 bauh akuarium (5 ekor per akuarium). Ikan diadaptasikan terlebih dahulu ke dalam wadah penelitian selama 2 hari agar ikan uji dapat menyesuaikan dengan kondisi lingkungan penelitian baik pakan maupun kualitas airnya. Selama masa adaptasi ikan komet diberi pakan komersial sebanyak 2 kali sehari.

\section{Pemeliharaan ikan komet}

Pemeliharaan ikan komet dilaksanakan selama 40 hari (Juli-Agustus 2020) di Laboratorium Unit Pembenihan dan Produksi ikan, Fakultas Perikanan dan Ilmu Kelautan, Universitas Halu Oleo, Kendari.Ikan komet diberi pakan uji sebanyak 3\% dari biomassa tubuh ikan dengan frekuensi 2 kali sehari yaitu pada pagi hari (pukul 08.00) dan sore hari (pukul 16.00).Pergantian air dilakukan melalui proses penyiponan. Penyiponan dilakukan setiap hari yaitu pada pagi hari sebelum pemberian pakan. Penyiponan bertujuan agar sisa-sisa pakan maupun sisa feses dapat dikeluarkan sehingga tidak terjadi penumpukan dan pembusukan pada media.

Penimbangan ikan komet dilakukan pada awal penelitian (hari ke-0) dan akhir penelitian (hari ke-40), dengan menggunakan timbangan analitik yaitu dengan cara ikan ditimbang satu per satu pada setiap perlakuan dan ditimbang secara basah. 


\section{Parameter yang Diamati}

\section{Performa Warna}

Penilaian performa warna ikan $\operatorname{komet}(C$. auratus) dilakukan dengan metode score sheetmenggunakan responden kuisioner (panelis) sebanyak 10 orang, masing-masing menilai tingkat kecerahan warna berdasarkan tabel score sheetdan dipastikan panelis tidak memiliki penyakitbuta warna.

Pengamatan dilakukan sebanyak 3 kali yaitu pada hari ke-0, hari ke-20 dan hari ke-40 pemeliharaan ikan. Pengamatan warna, dilakukan dengan masing-masing akuarium diberi label yang sesuai dengan perlakuan dan ulangan. Sedangkan pada hari ke-20 penelitian, masing-masing perlakuan dan ulangan diacak serta diberi nomor 1-12 secara berurutan, sedangkan untuk label perlakuan disimpan dan hanya ditandai oleh peneliti saja. Kondisi ini dimaksudkan agar menghindari subyektifitas dalam penilaian warna ikan oleh peneliti.

Metode score sheet ini mengacu kepada (Sugiyono2008),tingkat kecerahan baik warna orange maupun warna putih dibagi ke dalam empat kategori penilaian yaitu pudar (nilai 01,0 ), redup (nilai 1,1-2,0), cerah (nilai 2,1-3,0), dan sangat cerah (nilai 3,1-4,0). Penilain peforma warna ikan hias komet seperti ini disajikan pada Gambar 2.

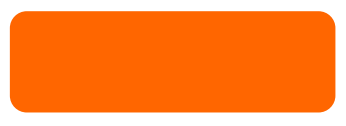

Orange Sangat

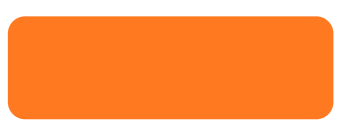

Orange cerah

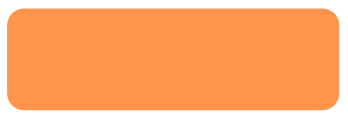

Orange redup

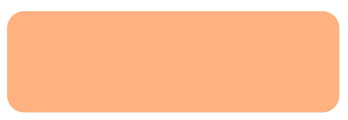

Orange pudar

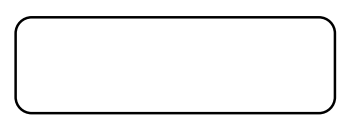

Putih Sangat Cerah

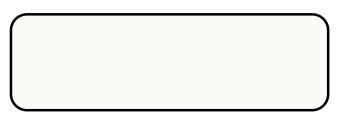

Putih Cerah

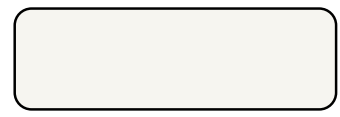

Putih redup

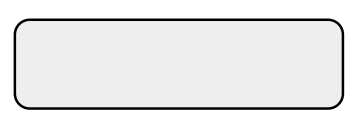

Putih Pudar
Gambar 2. Tingkat performa warna sebagai pedoman pengukuran kecerahan warna ikan komet (C. auratus)

\section{Pertumbuhan Mutlak}

Pertumbuhan mutlak ikan komet $(C$. auratus) dihitung dengan rumus $\mathrm{Hu}$ et al., (2008) yaitu:

$$
\mathrm{PM}=\mathrm{Wt}-\mathrm{W} 0
$$

Dengan: $\mathrm{PM}=$ Pertumbuhan mutlak rata-rata (g); Wt = Bobot rata-rata ikan pada waktu akhir penelitian $(\mathrm{g})$; $\mathrm{W} 0=$ Bobot rata-rata ikan pada waktu awal penelitian (g).

\section{Tingkat Kelangsungan Hidup}

Tingkat kelangsungan hidup atau Survival Rate (SR) diukur dengan menggunakan rumus menurut (Effendie, 2002) sebagai berikut:

$$
\mathrm{SR}=\frac{\mathrm{Nt}}{\mathrm{No}} \times 100 \%
$$

Dengan: SR= Kelangsungan Hidup (\%); $\mathrm{Nt}=$ Jumlah Ikan pada Akhir Penelitian (ekor); No= Jumlah Ikan pada Awal Penelitian (ekor).

\section{Kualitas Air}

Sebagai data penunjang maka akan dilakukan beberapa pengukuran parameter kualitas air seperti suhu, $\mathrm{pH}$, dan oksigen terlarut (DO).

\section{Analisis Data}

Penelitian ini menggunakan analisis ANOVA untuk mengetahui pengaruh perlakuan terhadap variabel yang diamati dan untuk menguji beda nyata antara perlakuan. Bila terdapat beda nyata diantara perlakuan maka dilakukan uji lanjut dengan menggunakan uji Duncan. Analisis statistik menggunakan SPSS versi 16.0.

\section{HASIL}

\section{Tingkat Kecerahan Warna Orange}

Pakan uji dengan penambahan tepung spirulina dengan jumlah yang berbeda memberikan pengaruh yang berbeda nyata terhadap tingkat kecerahan warna orange ikan komet selama 40 hari pemeliharaan $(\mathrm{P}<0,05)$ (Gambar 3). Nilai tingkat kecerahan warna orange didapatkan pada ikan komet adalah 1,96 (redup), 2,62, (cerah), 3,16 (sangat cerah), dan 
3,60 (sangat cerah) pada perlakuan pakan uji A, $\mathrm{B}, \mathrm{C}$ dan D secara berturut-turut.

\section{Tingkat Kecerahan Warna Putih}

Hasil tingkat kecerahan warna putih pada penelitian didapatkan pada pakan A adalah 1,78, (redup), pakan B adalah 1,92, (redup), pakan C adalah 2,6, (cerah), dan pakan D adalah 2,94 (cerah). Hasil analisis ragam menunjukkan bahwa pakan uji memberikan pengaruh berbeda nyata pada tingkat kecerahan warna putih ikan komet pada akhir penelitian $(\mathrm{P}<0,05)($ Gambar 4).

\section{Pertumbuhan Mutlak}

Gambar 5 menunjukkan bahwa nilai pertumbuhan mutlak tertinggi didapatkan pada perlakuan A yaitu sebesar 19,28 (g) dan terendah didapatkan pada perlakuan $\mathrm{D}$ yaitu 10,9 g. Hasil analisis ragam menunjukkan bahwa pakan uji yang diberikan tidak memberikan pengaruh nyata terhadap pertumbuhan mutlak ikan komet $(\mathrm{P}>0,05)$.

\section{Tingkat Kelangsungan Hidup}

Hasil pengamatan tingkat kelangsungan hidup ikan komet pada masing-masing perlakuan adalah $100 \%$ selama 40 hari pengamatan.

\section{Pengukuran Kualitas Air}

Hasil pengukuran kualitas air selema penelitian dapat dilihat pada Tabel 4 .

Tabel 4 . Hasil Pengukuran Kualitas Air Selama Penelitian

\begin{tabular}{lcl}
\hline Parameter & $\begin{array}{c}\text { Hasil } \\
\text { Pengukuran }\end{array}$ & \multicolumn{1}{c}{ Kisaran } \\
\hline Suhu $\left({ }^{\circ} \mathrm{C}\right)$ & $27-28$ & $\begin{array}{l}23-29 \text { (Lesmana, } \\
\end{array}$ \\
DO $(\mathrm{mg} / \mathrm{L})$ & $6,7-7,0$ & $\begin{array}{l}2007) \\
5,0-8,0 \\
(\text { Lesmana, 2007) }\end{array}$ \\
$\mathrm{pH}$ & $6,7-7,4$ & $\begin{array}{l}6,5-8,0 \\
\text { (Lesmana, 2007) }\end{array}$ \\
& &
\end{tabular}

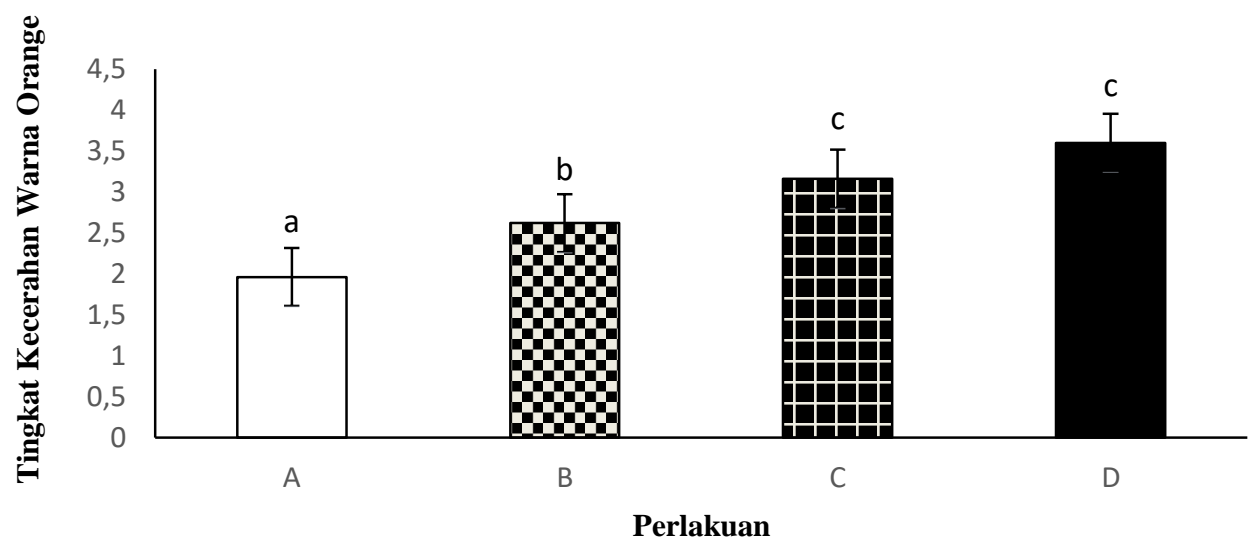

Gambar 3. Histogram Rata-Rata Peningkatan Kecerahan Warna Orange pada Ikan Komet (C. auratus) Hasil Penilaian Panelis.Perlakuan A (pakan kontrol); Perlakuan B (1\% pakan Spirulina); Perlakuan C (3\% pakan Spirulina); Perlakuan D (5\% pakan Spirulina). ${ }^{\mathrm{a}, \mathrm{b}}$ superscript yang berbeda menunjukkan perbedaan signifikan pada taraf $\alpha=0,05$. 


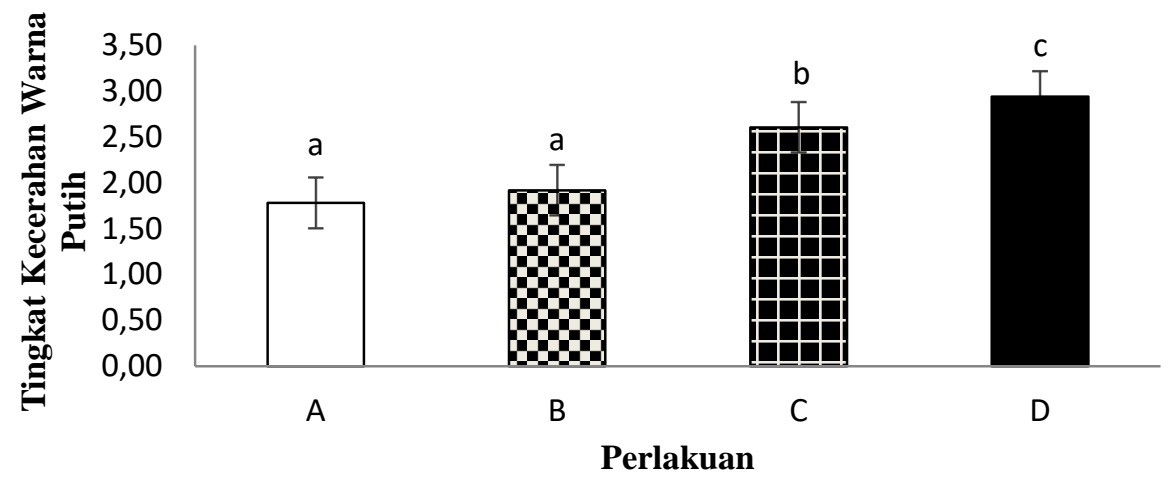

Gambar 4. Histogram Rata-Rata Peningkatan Kecerahan Warna Putih pada Ikan Komet (C. auratus) Hasil Penilaian Panelis.Perlakuan A (pakan kontrol); Perlakuan B (1\% pakan Spirulina); Perlakuan C (3\% pakan Spirulina); Perlakuan D (5\% pakan Spirulina). ${ }^{\mathrm{a}, \mathrm{b}}$ superscript yang berbeda menunjukkan perbedaan signifikan pada taraf $\alpha=0,05$.

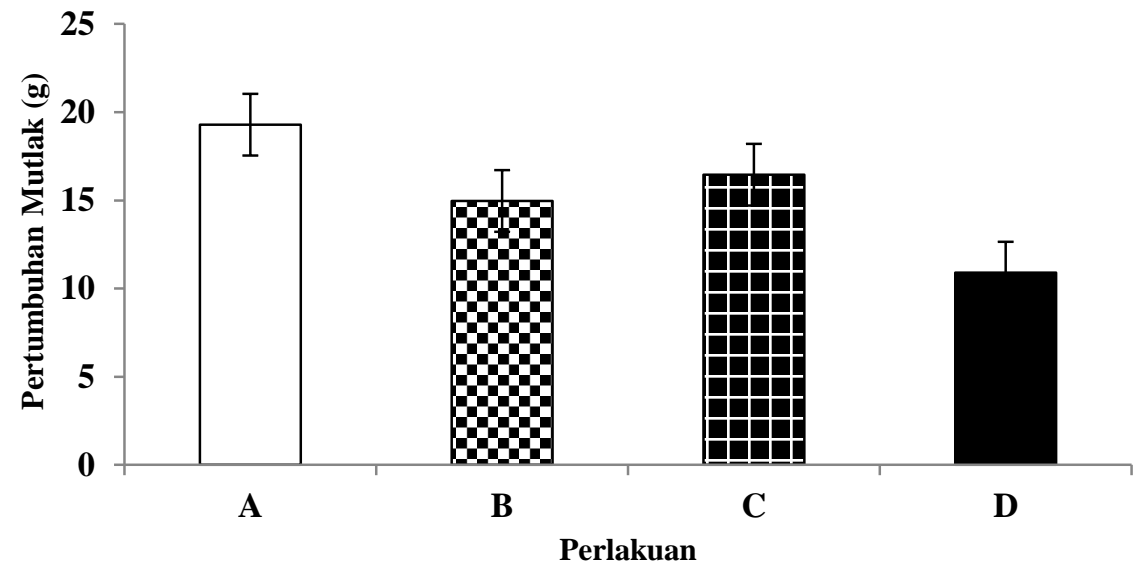

Gambar 5. Histogram Rata-Rata Pertumbuhan Mutlak pada Ikan Komet (C. auratus) Hasil Pertumbuhan mutlak. Perlakuan A (pakan kontrol); Perlakuan B (1\% pakan Spirulina); Perlakuan C (3\% pakan Spirulina); Perlakuan D (5\% pakan Spirulina).

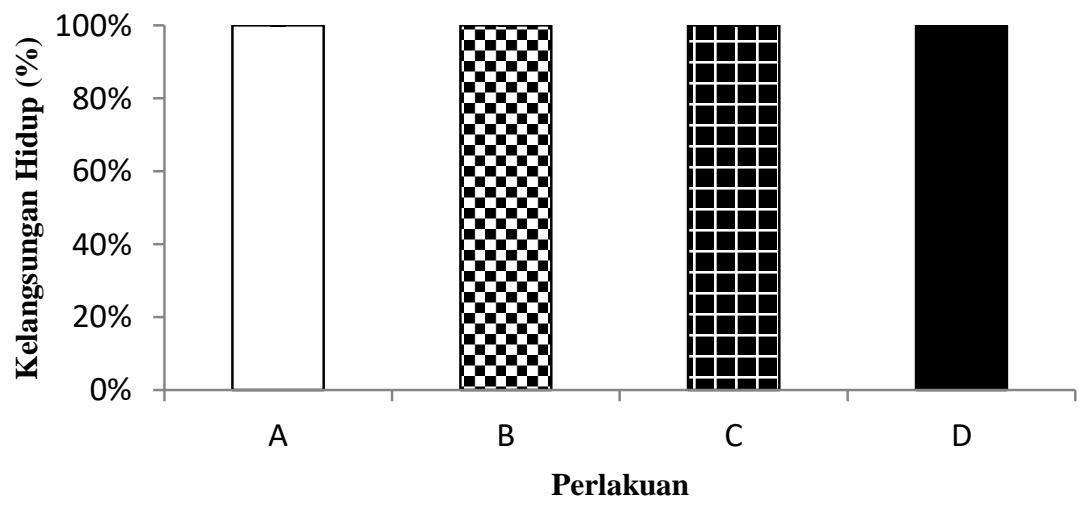

Gambar 6. Histogram Rata-Rata tingkat kelangsungan hidup pada Ikan Komet (C. auratus). Perlakuan A (pakan kontrol); Perlakuan B (1\% pakan Spirulina); Perlakuan C (3\% pakan Spirulina); Perlakuan D (5\% pakan Spirulina). 


\section{PEMBAHASAN}

Berdasarkan hasil penelitian menunjukan bahwa tingkat kecerahaan warna orange ikan komet yang diberi pakan yang mengandung tepung spirulina lebih tinggi dibanding kelompok ikan komet yang diberi pakan yang tidak mengandung tepung spirulina.Hal ini diduga karena tepung spirulina mengandung karetonoid yang tinggi. Sedangkan pakan kontrol (pakan komersil) diduga sedikit atau tidak mengandung karotenoid sehingga mengakibatkan kecerahan warna orange ikan komet menurun pada akhir penelitian. Hasil ini didukung oleh pernyataan Kaledupa (2018) bahwa tingkat kecerahan warna orange ikan komet yang diberi pakan kontrol juga menurun.

Peningkatan warna orange ikan komet yang diberi pakan yang tepung spirulina disebabkan karena dalam tepung spirulina mengandung karotenoid. Hal ini sesui dengan pernyataan Hariati (2008) menyatakan bahwa mikroalga jenis Spirulina sp. merupakan organisme autotroph berwarna hijau kebiruan terdiri dari sel-sel silindris yang membentuk koloni dimana selnya berkolom membentuk filament terpilin menyerupai spiral (helix) sehingga disebut juga alga biru hijau berfilamen.

Kemudian didukung dengan pernyataan Tietze (2004) menyatakan bahwa mikroalga Spirulina sp. merupakan jenis mikroalga golongan Cyanophyta atau alga hijau biru (bluegreen algae) yang telah banyak digunakan sebagai pakan alami dalam usaha budidaya khususnya dalam pembenihan karena memiliki nilai nutrisi yang tinggi. Kandungan protein pada Spirulina sp. berkisar antara 50-70\% dari berat kering. Penelitian Watanabe et al., (1990) menunjukkan bahwa pakan yang diberi tambahan Spirulina sp. dapat meningkatkan pertumbuhan dan rasio konversi pakan ikan striped jack (Pseudocaranx dentex). Tepung Spirulina banyak digunakan sebagai pakan tambahan ikan hias karena dapat menambah pewarnaan akibat pigmen yang terkandung didalamnya. Pigmen tersebut antara lain klorofil $(0,08 \%)$, beta-karoten $(0,23 \%)$ dan xanthofil $(0,12-0,5 \%)$. Selain sebagai pakan alami Spirulina sp.banyak digunakan sebagai imunostimulan, obat-obatan, kosmetik dan pewarna alami (Utomo et al., 2005). Tepung Spirulina memberikan pengaruh terhadap peningkatan intensitas warna pada ikan mas koki, dikarenakan Spirulina mengandung karotenoid yang dapat meningkatkan intensitas warna pada ikan (Sasson, 1991).Mikroalga Spirulina sp. merupakan mikroalga yang menyebar secara luas di alam dan dapat ditemukan di berbagai tipe lingkungan, baik di perairan payau, laut dan tawar (Ciferri, 1983).

Berdasarkan hasil penelitian pemberian pakan yang mengandung tepung Spirulina sp. terlihat bahwa semakin tinggi dosis tepung spirulina memberikan tingkat kecerahan warna semakin meningkat. Pemberian tepung spirulina dalam pakan $1 \%$, 3\% dan 5\% menghasilkan kecerahan warna orange yang lebih tinggi dibandingkan yang tidak diberi tepung spirulina. Sementara itu ikan komet yang diberi pakan yang mengandung tepung Spirulina,Berdasarkan hasil penelitian rata-rata pada tingkat warna orange ikan komet menunjukan bahwa peningkatan warna orange yang tertinggi yaitu 5\% terlihat bahwa penelitian terjadi peningkatan kecerahan warna orange menjadi 3,60. Hasil analisis statistik tentang pengaruh pemberian dosis tepung spirulina terhadap pewarnaan ikan komet yang menunjukkan bahwa pakan uji yang diberikan memberikan pengaruh berbeda nyata $(\mathrm{P}<0,05)$ terhadap tingkat kecerahan warna orange ikan komet pada perlakuan memberikan pengaruh yang berbeda nyata terhadap tingkat kecerahan warna ikan komet.Menurut pernyataan Yusniarti (2018) menunjukkan bahwa penambahan karotenoid yang terkandung dalam tepung buah manggis dapat mempengaruhi kecerahan warna ikan komet. Hal ini diperkuat dengan terjadinya peningkatan warna pada pengamatan akhir penelitian pada setiap perlakuan selama masa pengamatan.Hal ini diperkuat peningkatan warna pada selama masa pengamatan hasil penelitian rata-rata pada tingkat warna orange ikan komet menunjukan bahwa peningkatan warna orange yang tertinggi yaitu ikan komet yang diberi pakan 15\% tepung kulit buah manggis sebesar 4,52.

Hasil ini serupa dengan penelitian Andriani $d k k$ (2018) yang menyimpulkan bahwa pemberian $S$. platensis pada perlakuan $1 \%, 3 \%$, $5 \%$ dan $7 \%$ juga mengalami peningkatan warna, namun perubahan warna relatif tidak tinggi karena keempat perlakuan memiliki tingkat penyerapan yang berbeda terhadap dosis Spirulina platensis yang diberikan. Penambahan Spirulina platensis sebanyak 9\% merupakan 
hasil terbaik dan berpengaruh nyata terhadap perubahan warna ikan mas koki oranda. Kemudian didukung oleh pernyataan Nafsihi (2016) bahwa kandungan $\beta$-karoten dalam tepung Spirulina sp. dapat dimanfaatkan oleh ikan, terlihat dengan adanya perubahan warna ikan, makin tinggi penambahan tepung Spirulina sp. peningkatan kecerahan warna ikan semakin tinggi. Mekanisme peningkatan kecerahan warna dipengaruhi oleh sel pigmen (kromatofor) yang terletak pada lapisan epidermis (Sally, 1997: Walin, 2002).

Berdasarkan hasil penelitian menunjukan pemberian tepung Spirulina dengan dosis yang berbeda, memberikan respon yang berbeda terhadap tingkat kecerahan warna orange ikan komet. Pakan yang diberi pigmen atau pakan yang mengandung pigmen yaitu tepung Spirulina lebih tinggi dibandingkan dengan pakan komersil yakni ikan sudah memanfaatkan pigmen warna yang dihasilkan oleh tepung spirulina. Hasil ini didukung dengan pernyataan Sasson (1991) bahwa, tepung spirulina memberikan pengaruh terhadap peningkatan intensitas warna pada ikan mas koki, dikarenakan Spirulina mengandung karotenoid yang dapat meningkatkan intensitas warna pada ikan.Kemudian didukung dengan pernyataan Utomo $d k k$. (2005) menyatakan bahwa pakan yang mengandung karotenoid yang lebih tinggi mampu menghasilkan performasi warna yang baik. Berdasarkan penelitian Iskandar (2015) menyatakan bahwa, semakin tinggi dosis buah merah yang diberikan maka tingkat kecerahan warna pada ikan komet akan semakin meningkat dimana telah dibandingkan antara dosis buah merah yang diberikan yaitu $1 \%, 3 \%$ dan $5 \%$ tingkat kecerahan warnanya lebih meningkat pada dosis $5 \%$.

Pemberian pakan uji terhadap peningkatan kecerahan ikan komet lebih dominan warna orange dibandingkan dengan kecerahan warna putih yang dapat diekspresikan oleh ikan kometpakan 5\% lebih tinggi dibanding pakan $0 \%, 1 \%$, dan 3\%, namun diduga bahwa pakan yang mengandung tepung spirulina cenderung terhadap warna orange. Hasil ini dibuktikan dengan nilai yang ada pada peningkatan kecerahan warna orange. Demikian pula dengan warna putih dari keseluruhan pakan uji yang diberikan pakan 5\% lebih cenderung tinggi dibanding ikan komet yang diberi pakan $0 \%$, pakan $1 \%$, dan pakan $3 \%$, namun diduga pula bahwa pakan Spirulina cenderung terhadap warna putih. Hasil analisis statistik tentang pengaruh pemberian dosis tepung Spirulina terhadap pewarnaan ikan komet yang menunjukkan bahwa pakan uji yang diberikan berbeda nyata $(\mathrm{P}<0,05)$ terhadap tingkat kecerahan warna putih ikan komet. Namun warna putih pada dasarnya bukan pada karotenoid yang mengandung pigmen warna karena senyawa warna putih tidak mengandung pigmen warna. Hal ini sesui dengan pernyataan Wahyuni (2018) menyatakan bahwa rendahnya pada ikan nemo warna putih yang dapat diekspresikan setelah pemberian pakan dimana hal ini diasumsikan karena tidak adanya senyawa yang dapat meningkatkan kecerahan warna putih dibandingkan kecerahan warna orange yang dapat diekspresikan.Tingkat kecerahan warna pada ikan hias menjadi salah satu indikator dalam penentuan kualitas dan harga jual, sehingga ikan tersebut akan memiliki nilai ekonomis tinggi. Salah satu bahan pakan yang mengandung pigmen warna adalah tepung Spirulina yang dapat meningkatkan intensitas kecerahan warna dengan pemberian koroten atau karotenoid. Kemudian didukung dengan pernyataan Sasson (1991) bahwa, tepung spirulina memberikan pengaruh terhadap peningkatan intensitas warna pada ikan mas koki, dikarenakan Spirulina mengandung karotenoid yang dapat meningkatkan intensitas warna pada ikan.

Pertumbuhan pada ikan komet dapat mempengaruhi perubahan warna atau warna akan memudar yang dikarenakan tubuh ikan yang membesar sehingga warna pada ikan akan menyebar. Hasil penelitian pemberian tepung Spirulina dalam pakan 1\%, 3\% dan 5\% tidak memberikan pengaruh pertumbuhan terhadap ikan hias komet dan hasil analisis ragam menunjukkan bahwa pakan uji yang diberikan tidak memberikan pengaruh nyata $(\mathrm{P}>0,05)$ terhadap pertumbuhan mutlak ikan komet. Hal ini serupa dengan pernyataan Nafsihi (2016) bahwa dalam pengamatan pertumbuhan panjang mutlak tidak mengalami perbedaan yang signifikan antar perlakuan. Hal ini dikarenakan pertumbuhan panjang tidak memberikan pengaruh yang nyata terhadap kecerahan warna ikan dengan penambahan pakan tersebut.Hal ini diduga karna tepung Spirulina tidak memberikan pengaruh terhadap pertumbuhan pada ikan komet tetapi hanya memberikan 
pigmen warna yang mengandung karotenoid. Hal ini diduga karena pakan yang diberikan pada setiap perlakuan tidak memiliki protein yang berbeda untuk mencukupi kebutuhan pertumbuhan ikan koki melainkan ditambahkan bahan sumber karoten sebagai peningkat intensitas warna ikan koki. Berdasarkan hasil penelitian yang dilakukan dengan menggunakan empat jenis pakan buatan yang berbeda memberikan tingkat pertumbuhan yang beragam. Adapun pakan buatan yang diujikan yaitu perlakuan $0 \%$ pakan kontrol, perlakuan $1 \%$ tepung spirulina, perlakuan $3 \%$ tepung Spirulina, dan perlakuan 5\% tepung spirulina.

Hasil pengamatan tingkat kelangsungan hidup ikan komet pada masing-masing perlakuan selama penelitian adalah $100 \%$ diduga karena nutrisi pakan (protein, lemak, karbohidrat, vitamin dan mineral) telah memenuhi kebutuhan ikan komet. Parameter kualitas air yang diamati pada penelitian ini adalah suhu, $\mathrm{pH}$, dan DO, masih dalam batas toleransi. Hal ini dapat dilihat dari parameter suhu selama penelitian berkisar berkisar antara $26,5-27^{\circ} \mathrm{C}$. Kisaran $\mathrm{pH}$ yang diukur pada wadah pemeliharaan setiap perlakuan berkisar antara 6,7-7,4. Menurut Lesmana (2007), bahwa pH yang optimal pada pemeliharaan Ikan Maskoki berkisar antara 6,5-8,0. Sehingga $\mathrm{pH}$ pada wadah pemeliharaan tidak mengganggu pertumbuhan dan kelangsungan hidup ikan uji. Hal ini didukung dengan pernyataan Andriani $d k k$. (2018) menyatakan bahwa nilai $\mathrm{pH}$ yang terukur selama penelitian pada setiap akuarium tidak berbeda satu sama lain yaitu berkisar antara 7-8. Hasil pengamatan DO selama penelitian didapatkan rata-rata DO setiap perlakuan yaitu 5,0-6,0 mg/L. Dari hasil ratarata setiap perlakuan selama penelitian tersebut dapat dikatakan masih layak untuk pemeliharaan ikan hias. Hal ini didukung dengan pernyataan Nafsihi (2016) yang menyatakan bahwa selain pakan yang mengandung sumber karotenoid, faktor lain yang mempengaruhi kecerahan warna ikan adalah kualitas air. Selama penelitian, parameter kualitas air dalam kisaran normal, sehingga tidak berpengaruh terhadap kehidupan dan pertumbuhan ikan.

\section{KESIMPULAN}

Penambahan tepung spirulina dalam pakan dapat meningkatkan kecerahaan warna ikan komet. Pemberian tepung Spirulina dengan dosis sebanyak 5\% dalam pakan dapat menghsilkan tingkat kecerahan warna ikan komet (Carrasisu auratus).

\section{REFERENSI}

Andriani, Y., Alamsyah, A., \& Lili, W. (2018). Effect of Dietary Supplementation of Spirulina Platensis and Carrot Meal to Enhance Color Brightness of Oranda Goldfish (Carassius auratus). Jurnal Perikanan dan Kelautan, 8(1): 1-9. http://dx.doi.org/10.33512/jpk.v8i1.3679

Andriani, Y., Maesaroh, T. R. S., Yustiati, A., Iskandar, I., \& Zidni, I. (2018). Kualitas Warna Benih Ikan Mas Koki (Carassius auratus) Oranda Pada Berbagai Tingkat Pemberian Tepung Spirulina platensis. Chimica et Natura Acta, 6(2): 49-55. https://doi.org/10.24198/cna.v6.n2.16341

Bachtiar, Y. (2002). Pembesaran Ikan di Kolam Pekarangan. Jakarta: Agro Media Pustaka. Jakarta

Ciferri, O. (1983). Spirulina, the edible microorganism. Microbiological reviews, 47(4): 551.

Effendie. M.I. (2002). Biologi Perikanan. Yayasan Pustaka Nusantara. Yogyakarta.

Hu, Y., Tan, B., Mai, K., Ai, Q., Zheng, S., Cheng, K. (2008). Growth and Body Composition of Juvenil White Shrimp, (Litopanaeus vanamei), Fed Different Ratios of Dietary Protein to Energy. Jurnal Aquaculture Nutrition, 14(6): 499506. https://doi.org/10.1111/j.13652095.2007.00555.x

Kaledupa, N., Kurnia, A. dan indriyani N. (2018). Studi Pemanfaatan Kulit Buah Naga Merah (Hylocereus polyrhizus) dalam Pakan Terhadap Pewarnaa Ikan Mas Koi (Cyprius carpio L.). Media Akuatika, 3(1): 590-597.

Kurnia, A., \& Muskita, W. H. (2017). Tampilan warna ikan maanvis, Pterophyllum scalare Schultze 1823, yang diberi pakan tepung udang dan tepung wortel [Color performance of angel fish, Pterophyllum scalare Schultze 1823 that fed shrimp meal and carrot meal]. Jurnal Iktiologi Indonesia, 13(2): 187-195.

Lesmana, D.S. (2007). Budidaya Ikan Hias Air Tawar Populer. Panebar Swadaya. Jakarta. 
Lesmana dan Satyani, D. (2002). Agar Ikan Hias Cemerlang. Penebar Swadaya. Jakarta.

Nafsihi, N., Hudaidah, S. \& Supono. (2016). Pemanfaatan tepung Spirulina sp. untuk meningkatkan kecerahan warna ikan sumatra (Puntius tetrazona). e-Jurnal Rekayasa dan Teknologi Budidaya Perairan, 4(2): 523-528.

Sally, E. (1997). Pigment Granula Transport in Cromatophores. Departement of Biology Bucknell University, Lewisburg.

Sasson, A. (1991). Culture of microalgae in achievement and evaluation. United Nation Educational, Scientific and Cultural Organitation (UNESCO) Place de Pontenry, Paris. France.

Sugiyono. (2008). Metode Penelitian Kuantitatif, Kualitatif dan R\&D. Alfabeta. Bandung.

Barus, R. S., Usman, S., \& Nurmatias, N. (2014). Pengaruh Konsentrasi Tepung Spirulina Platensis Pada Pakan Terhadap Peningkatan Warna Ikan Maskoki (Carassius auratus) [Effect of Spirulina platensis Concentration in Diet to Increase Color of Goldfish (Carassius auratus)]. Aquacoastmarine, 5(4).

Tietze, H.W. (2004). Spirulina micro food macro blessing (4th edition). Harald $\mathrm{W}$. Tietze Publishing. Australia.

Utomo, N. B. P., \& Winarti, dan A. Erlina. (2005). Pertumbuhan Spirulina platensis yang dikultur dengan pupuk inorganik (Urea, TSP dan ZA) dan kotoran ayam. Jurnal Akukultur Indonesia, 4(1):41-48.

Wahyuni, S.N. (2018). Pengaruh Penambahan Tepung Kulit Buah Manggis (Garcinia $\begin{array}{lll}\text { Mangostana L.) Terhadap Tingkat } & \end{array}$ Kecerahan Warna Ikan Nemo (Amphiprion percula). Skripsi. Fakultas Perikanan dan Ilmu Kelautan. Universitas Halu Oleo. Kendari.

Walin, M. (2002). Natures Palette How Animals, Including Humans, Produce Colours. Departement of Zoology Goteborg University. Sweden.

Watanabe T, Liao WL, Takeuchi T, Yamamoto H. (1990). Effect of dietary Spirulina supplementation on growth performance and flash lipid of cultured striped jack . J Tokyo Univ Fish, 77: 231-239.

Yusniarti, Muskita, W., \& Kurnia, A. (2018). Studi Pemanfaatan Tepung Kulit Buah
Manggis (Garcinia mangostana L.) untuk Pewarnaan Ikan Hias Komet (Carassius auratus). Jurnal Media Akuatika, 3(2): 659-669. 